\title{
Environmental Mapping of Potential Habitats for Anthropod Vectors of Trypanosomiasis in Northern Nigeria
}

\author{
Sadiq Abdullahi Yelwa*, Kabiru Bilalu, Abdulhamid Yahuza, Nura Garba \\ Department of Environmental and Resources Management, Faculty of Engineering and Environmental Design, Usmanu \\ Danfodiyo University, Sokoto, Nigeria \\ Email: *sadiq.abdullahi@udusok.edu.ng
}

How to cite this paper: Yelwa, S. A., Bilalu, K., Yahuza, A., \& Garba, N. (2021). Environmental Mapping of Potential Habitats for Anthropod Vectors of Trypanosomiasis in Northern Nigeria. Journal of Geoscience and Environment Protection, 9, 34-51.

https://doi.org/10.4236/gep.2021.99003

Received: August 1, 2021

Accepted: September 15, 2021

Published: September 18, 2021

Copyright $\odot 2021$ by author(s) and Scientific Research Publishing Inc. This work is licensed under the Creative Commons Attribution International License (CC BY 4.0).

http://creativecommons.org/licenses/by/4.0/

\begin{abstract}
This paper presents analysis of a cost effective methodology using remotely sensed data analysed within a geographical systems (GIS) environment for mapping out potential habitats of anthropod vectors responsible for trypanosomiasis in northern Nigeria. These geographical locations are areas with high population of livestock in Nigeria. Animal Trypanosomiasis is considered as an arthropod-borne viral disease which is endemic in about 37 countries of the sub-Saharan Africa and in particular northern Nigeria. This anthropod-borne viral disease remains a threat to both humans and livestock in many communities, and the outbreak of such diseases is shown to relate to fluctuations in the changing climate mostly experienced whenever there are changes in global precipitation which also relates to changes in sea surface temperatures otherwise known as "El Niňo Southern Oscillations" (ENSO). Monthly Satellite imageries in the form of Normalised Difference Vegetation Index (NDVI) at 250 meters spatial resolution obtained from NASA-MODIS/CMD were subjected to principal component analysis utilizing the standardized principal components within a GIS environment and supplemented with Digital Elevation Model (DEM) data in the analysis. Results from the maps showed that pockets of probable habitats of these anthropod vectors responsible for trypanosomiasis mostly located around forest islands characterized by dry woodland and savanna, and in some cases around gallery forests and few lowland and riverine areas. This study provides baseline information for policy makers in Nigeria and other stakeholders as a cost effective measure for mapping potential habitats for anthropod vectors responsible for trypanosomiasis in Northern Nigeria. Further studies are encouraged so as to clearly understand the magnitude and actual loca-
\end{abstract}


tions of the habitat of this vector and find ways of targeting their locations for minimizing or even eradicating these vectors.

\section{Keywords}

Trypanosomiasis, Habitat, Cost Effective Measures, Principal Component Analysis (PCA), El-Niño Southern Oscillations (ENSO)

\section{Introduction}

\subsection{Background}

Vector-Borne Diseases (VBDs) are human illnesses caused by parasites, viruses and bacteria that are transmitted by vectors. According to Yu et al.; 1995; Simarro et al., 2012; Franco et al., 2014 and Meyer, et al., 2016, African animal trypanosomiasis for example, is caused by several species of trypanosomes. In particular, the Trypanosoma congolense is found in most domestic mammals such as cattle, sheep, goats, horses, pigs, camels and dogs; and also in many wild animals. According to factsheet of the FAO in Nigeria (2020), the disease is endemic in about 37 countries of the sub-Saharan Africa, and tsetse flies are said to be the natural vectors of African trypanosomiasis which remains a threat to both humans and livestock in many rural communities. This disease which is infectious, is usually progressive and fatal if untreated, and, the vaccine production has not been successful (ILRAD, 1993). Cyclical transmission, during which the trypanosomes actively multiply in the vectors, occurs through the intermediary of Glossina or tsetse flies which are responsible for human sleeping sickness. The people most expose to the tsetse fly and therefore the disease live in rural areas and depend on agriculture, fishing, animal husbandry or hunting. Human African trypanosomiasis takes two forms, depending on the parasites involved, for example, Trypanosoma brucei gambiense accounts for more than $98 \%$ of reported cases (WHO, 2017, 2020). Sustained control efforts have reduced the number of new cases. In 2009 the number was reported to have dropped below 10,000 for the first time in 50 years, and in 2015 there were 2804 cases recorded. Based on the current disease distribution as per the WHO report, it differs from country to country. Countries such as Angola, Burkina Faso, Cameroon, Chad including Nigeria reported fewer than 100 new cases per year.

Based on the global control responses by World Health Organisation (WHO, 2017) termed "Global Vector Control Response (GVCR) 2017-2030", there is strategic guidance provided to countries and development partners for urgent strengthening of vector control as a fundamental approach to preventing disease and responding to outbreaks. To achieve this according to WHO, a re-alignment of vector control programme is required, and supported by increased technical capacity, improved infrastructure, strengthened monitoring and surveillance system, and greater community mobilization. However, although there are other 
biologically-based control measures on animal trypanosomiasis such as action on parasites, action on host animals and action on the vectors themselves, it should be widened-up to support implementation of a comprehensive approach to vector control that will enable the achievement of disease-specific national and global goals and contribute to achievement of the Sustainable Development Goals and Universal Health Coverage. Furthermore, according to WHO (2017) reports, data on the costs of tsetse fly control are numerous but difficult to compare because they depend on many factors, especially; the evaluation of the area of a cleared zone and its relation to the area actually treated, the accounting system used for certain expenses (management personnel, equipment amortization), the expenses involved in preliminary surveys, subsequent surveillance and conservation measures, and the utilization of the cleared zone.

Accordingly, some studies on the outbreak of such diseases were shown to relate to fluctuations in the climate which also affects changes in sea surface temperatures otherwise called "El Niňo Southern Oscillations" (ENSO) phenomenon (Rogers et al., 1996; Kogan \& Wei, 2000; Anyamba et al., 2001). This is the time mostly when changes in global precipitation and biomass is also experienced. Thus, any environmental change whether natural or human induced can alter ecological balance. During this period, vectors and their parasites can breed, develop and transmit disease particularly when they inhabit forest islands characterized by dry woodland and savanna, and in some cases around gallery forests. However, climate change will influence human vulnerability to vector-borne disease by influencing the seasonality and the location of exposures to pathogens and vectors. These impacts may also influence future disease patterns such that certain vector-borne diseases may emerge in areas where they had previously not been observed and other diseases may become less common in areas where they had previously been very common. With regard to the control of tsetse vectors that transmit trypanasomiasis, one of such control strategies is to eliminate or minimize the fly-to-man, or fly-to-host contact by creating a protective barrier in which a control scheme is employed to prevent the spatial progression of trypanosomiasis (Matzke, 1983; Bourn et al., 1994; WHO, 2017). In line with such efforts to control this endemic disease, Laird 1977; and Dransfield et al., 1991 studied the dynamics of tsetse flies over several decades and in different parts of Africa using various methods including capture-recapture experiments but did not achieve the desired results. However, Roger et al., 1996; Samdi et al., 2010; Simarro et al., 2012; Franco et al.; 2014 and Meyer, et al., 2016 experimented another technique with the data acquired through environmental remote sensing technology so as to have a better understanding of the fly movement into tsetse-free regions. In Nigeria today, and in particular, Northern $\mathrm{Ni}$ geria where there is high livestock production (Bourn et al., 1994) it has indeed contributed immensely to the protein need of humankind, as it is claimed to contribute too, to the socioeconomic growth of Nigerian state particularly, through its commercial farming with modern technique, and it is expected to 
enhance development in a way that will guaranteed food sufficiency. Accordingly, about 60 percent of the ruminant livestock population is found in the country's semi-arid zone of the country mostly managed by pastoralist accounting for $40 \%$ of the livestock contribution to the nation's GDP (FAO in Nigeria, 2020), and major intervention pivot that support or increase the productivity of agricultural development in Nigeria (Ari et al., 2016). In view of this, it is highly desirable that a cost effective measures be employed particularly with the aid of satellite imageries so that the habitats of these vectors within northern Nigeria be identified, isolated and targeted as part of the efforts to control this endemic disease.

\subsection{Satelite-Based Vegetation Indices Used in Related Studies}

There are several indices for accent vegetation-bearing areas on satellite datasets which were used in research in recent times. They include, Ratio Vegetation Index (RVI), Leaf Area Index (LAI), Difference Vegetation Index (DVI), Green Vegetation Index (GVI), Perpendicular Vegetation Index (PVI), Atmospherically Resistant Vegetation Index (ARVI); Soil-Adjusted Vegetation Index (SAVI); Enhanced Vegetation Index (EVI); Vegetation Condition Index (VCI) and Normalised Difference Vegetation Index (NDVI). However, the NDVI is a general and most extensively used index (e.g. Eastman \& Fulk, 1993; Millington et al., 1994; Chen, 1996; Mas, 1999; Anyamba et al., 2001; Lu et al., 2004; Drissi et al., 2009; Yelwa \& Eniolorunda 2012; Bhunia \& Shit, 2013; Xue \& Su, 2017; Yelwa \& Usman, 2017; Yelwa et al., 2019; Abdullahi \& Yelwa, 2020).

Furthermore, studies conducted by other researchers (e.g. Anyamba \& Eastman, 1996; Sutherst, 1998; Anyamba et al., 2001; Anyamba et al., 2002) also indicated that changing environmental conditions has led to changes in how and where plants, animals and people contact diseases. Thus, NDVI datasets have been used for detecting spatio-temporal changes, because in most cases it provides measure of the amount and vigor or otherwise of vegetation on the land Surface, and its magnitude is also related to the level of photosynthetic activity in the vegetation being observed by different satellite sensors in the electromagnetic spectrum (EMS). In the absence of rainfall information, NDVI datasets serve as surrogate to rainfall data because of their strong correlation. NDVI is derived from the ratio of the red and Near Infrared of a sensor system used to acquire the remotely sensed data. Thus, NDVI $=($ Near Infrared - Red $) \div($ Near Infrared + Red).

One of the different ways of categorising different types of vegetation cover using time-series datasets is by utilizing principal component analysis (PCA). This is because it has been experimented successfully in environmental remote sensing analysis for data transformation, information compression, and change detection studies. When PCA is used with standardised principal components in a geographical information systems (GIS) environment, it indicated clearly that the major element of variability is that which occurs spatially (Singh \& Harrison, 
1985; Eastman \& Fulk, 1993; Anyamba et al., 2001; Bhunia \& Shit, 2013; Yelwa \& Usman, 2017; Yelwa et al., 2019). PCA normally allows any set of original satellite imageries to be transformed to a set of new images (referred to as components) where such component images contain all of the information in the original images entered into such time-series are uncorrelated with one another (Richards, 1984). The interpretation of the extracted component images thus, relies on a combination of spatial and temporal analysis. The aim of the earlier studies particularly dealing with vector-borne diseases was to sensitise relevant authorities and stakeholders to take necessary steps so as to deal with the threat of the trypanosome vector rather than waiting until an outbreak manifested.

\subsection{Objectives}

Despite all the measures taken to convert animal trypanosomiasis the disease is said to be prevalent in northern Nigeria due to the presence of the tsetse flies with high mortality of livestock (Kalu, 1996; Ameh et al., 2000). However, Allsopp 2001 agues that those tasked with managing trypanosomiasis or committed to poverty alleviation in Africa should consider large-scale, area-wide tsetse control involving all proven methods like aerial spraying and the sterile insect technique. Thus, Wilson, et al. (2020) suggested that environmental management as the primary tool for control vector-borne-diseases (VBD) should focus on understanding local vector behavioural ecology and tailored environmental control, and on locating the habitats where the vectors develop. The objectives of this study therefore, is to present a cost effective approach using remotely sensed data analysed within a GIS environment such that probable habitats of vectors responsible for trypanasomiasis particularly in northern Nigeria can be identified and highlighted. Once these habitats are identified on the satellite imageries they can be targeted easily with the aim of minimizing or even eradicating the vectors.

\section{Data and Methods}

For this study, data for 5 years (2005 to 2009) amounting to sixty (60) monthly time-series satellite imageries in the form of Normalised Difference Vegetation Index (NDVI) at 250 meters spatial resolution was acquired from National Aeronautics Space Administration (NASA)'s Moderate Resolution Imaging Spectrometer (MODIS) Climate Modelling Grid (CMD). The coordinates corresponding to the study area covering the northern part of Nigeria was windowed using the Idrisi TerrSet raster-based remote sensing and GIS software. Water bodies were masked out to zero in order to ease the analysis. Digital Elevation Model (DEM) covering the same study area was also extracted from a complete DEM covering Nigeria and overlaid with the NDVI dataset to supplement the analysis. The NDVI time-series dataset was subjected to Principal Component Analysis utilizing the standard principal components where the 
original satellite imageries were transformed to a set of new images (as component imageries) and another set of loading scores corresponding to the number of the NDVI time-series dataset. The resultant component images contain all of the information in the original dataset (images) used as input into the PCA analysis. The extracted DEM of the study area was supplemented in the analysis through overlay procedure with the change component images derived from the PCA so as to determine the approximate elevation to enable digitisation of the probable areas that serve as habitats for these disease vectors.

\section{The Study Area}

The study area which is centred on Northern Nigeria (covering a rectangular area of the satellite imagery being utilised) includes parts of the southern part of Niger Republic in the north, Lake Chad in the north-east, Cameroon in the south-east and Republic of Benin in the west bounded within Latitude $06^{\circ} 39^{\prime}$ to $14^{\circ} 19^{\prime} \mathrm{N}$ and Longitude $02^{\circ} 23^{\prime}$ to $14^{\circ} 91^{\prime} \mathrm{E}$. The climatic condition of the northern part of Nigeria exhibit only two distinct seasons, namely, short rainy and an extended dry season. There are 19 states and Federal Capital Territory (FCT) that comprised the northern part of the country (Figure 1). The mean monthly temperatures during the day can exceed $36^{\circ} \mathrm{C}$ while the mean monthly temperatures at night in many instances fall to about $22^{\circ} \mathrm{C}$. According to White (1983) however, the annual rainfall in the northern part of the study area (southern part of Niger Republic and the extreme northern part of Nigeria) falling in the savanna vegetation zone of the country is not only $(50-100 \mathrm{~mm})$ less than in the rainforest and other parts of the southern forested areas of Nigeria, (i.e. the Niger Delta, the Cameroon and southern part of Republic of Benin) but the distribution throughout the year is less even. The rainy season also varies, as it ranges from eight to ten months in the southern forest zones (towards the southern part of the study area) to less than four months in the extreme northern savanna (towards the sahel on the Nigeria-Niger border). However, the rainfall variation from the northern to the southern part is attributed to the fluctuation of ITCZ (Oguntoyinbo, 1982). The ITCZ reaches its northernmost position near the $19^{\text {th }}$ parallel in mid-August, when sahel rainfall peaks, and after August, retreats rapidly southwards from June to September.

\section{Results and Discussion}

Results from the analysis produced two forms of output namely, sixty (60) component images and their respective sixty (60) standard scores, referred to as "component loadings". Although there are up to these numbers of component images and loading scores the analysis is however, limited to only four components as extensive ground truthing and environmental data are required to conduct further assessment if all the component images are to be explained. However, loading scores for components 5 to 8 (Table 1 ) are only presented in this study for visualization because the results from them are be attributed to very 


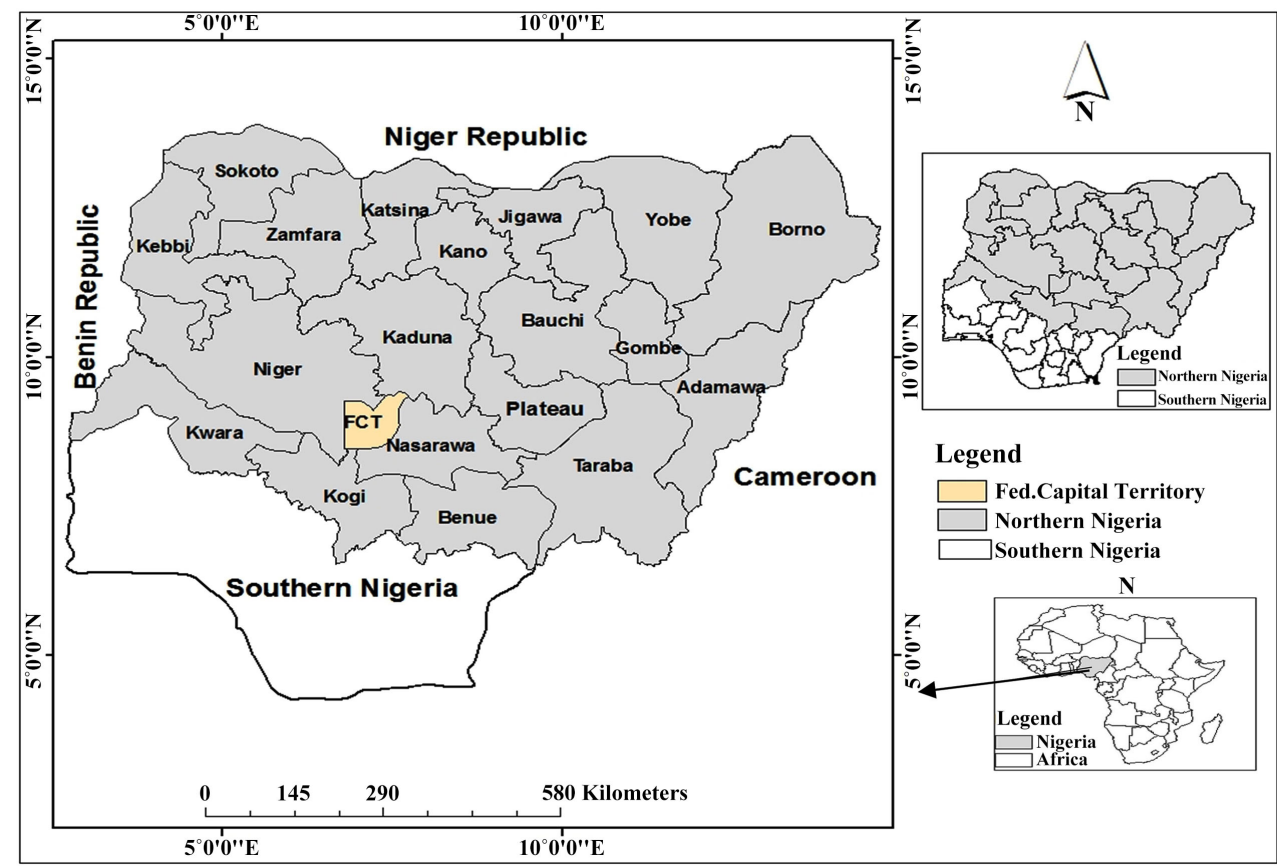

Figure 1. Map of the study area showing northern Ngeria.

Table 1. Percentage variance of component images.

\begin{tabular}{cc}
\hline Component Image & \% Variance with the total Dataset \\
\hline Comp 1 & 80.81 \\
Comp 2 & 8.44 \\
Comp 3 & 1.9 \\
Comp 4 & 1.19 \\
Comp 5 & 0.65 \\
Comp 6 & 0.53 \\
Comp 7 & 0.45 \\
Comp 8 & 0.4 \\
\hline
\end{tabular}

(Source: PCA Analysis).

localised events related to anthropogenic activities and changes in savanna vegetation typical of northern Nigeria which may be difficult to verify at the moment. As mentioned earlier these may be very difficult to explain without comprehensive ground truthing across the study area and available socio-economic data. The study conducted by Rogers et al. (1997) using NDVI covering Nigeria for example, revealed spatial patterns of NDVI relating to seasonal and annual variations across the whole country, in addition to pattern of changes which is likely related to localised events such as possible habitats of the vectors responsible for trypanosomiasis. Furthermore, it should be noted that vegetation influences energy balance at the boundary layer, often mitigating extremes of local climate (Olagunju, 2015). Accordingly, the resulting component 2 to 4 images from the PCA analysis of this NDVI time-series dataset suggest that there are 
some environmental implications particularly resulting from breeding habitats for vector-borne diseases as a result of global change and climatic variability which correlates with studies conducted by Matzke, 1983; Anene et al., 1991; Hay et al., 1997; Kalu, 1995; 1996; Patz et al., 2000 and Ameh et al., 2000. For most of the pockets vegetated areas that are indicative of either negative or positive anomalies as the PCA results have shown, they represent areas of ecological zones of special concern. A look at the loading graphs of these components and the digital elevation model overlaid on them to supplement the analysis indicate that the areas that are vulnerable are those slightly above 1000 metes above mean sea level around montane areas of plateau and Adamawa States. On the other hand, other areas that serve as probable habitats along the river banks and other localities are average between 300 to 600 meters above sea level. As Adamu, (2007) further noted, dense vegetation provides habitat to wildlife and other ecosystem as well as services such as food and fuel, timber, cash crops, pulp, fruits, robes, clothes and many game reserves. These may also serve as probable habitats of such vectors (Table 2).

\subsection{Component 1 and Loading Scores}

On the image in Figure 2(b) the component image explains about $81 \%$ of the total variance in the 60 NDVI time series dataset used in the PCA procedure. It illustrates a representative vegetation pattern across Northern Nigeria and partly from southern part of Niger Republic, Republic of Benin and Cameroon. This image represents the spatial variability of the NDVI across the time-series with the loading score exhibiting high scores (approximately close to 1). Areas that are less correlated with the loading scores are located from the northwest to the

Table 2. Location of the probable habitats within the northern states in Nigeria.

\begin{tabular}{ccc}
\hline S/No. & Habitat ID. & Location within state/s \\
\hline 1 & A & Jigawa/Yobe \\
2 & B & Borno \\
3 & C & Borno \\
4 & D & Gombe \\
5 & E & Plateau \\
6 & F & Adamawa \\
7 & G & Benue/Taraba \\
8 & H & Taraba \\
9 & I & Kogi \\
10 & J & Kogi \\
11 & K & Niger/Kwara \\
12 & L & Niger \\
13 & M & Kaduna \\
\hline
\end{tabular}

(Source: GIS Analysis). 


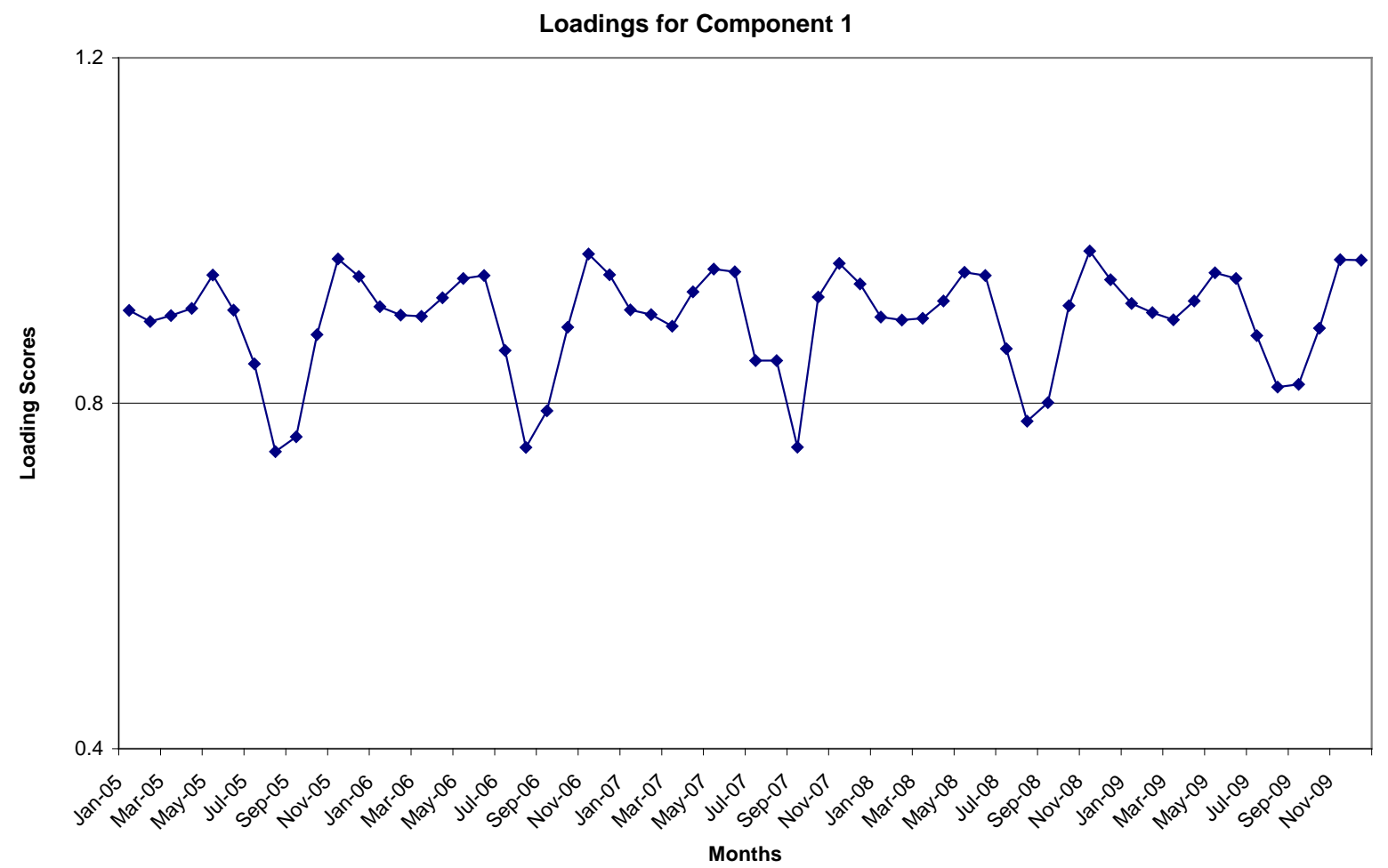

(a)

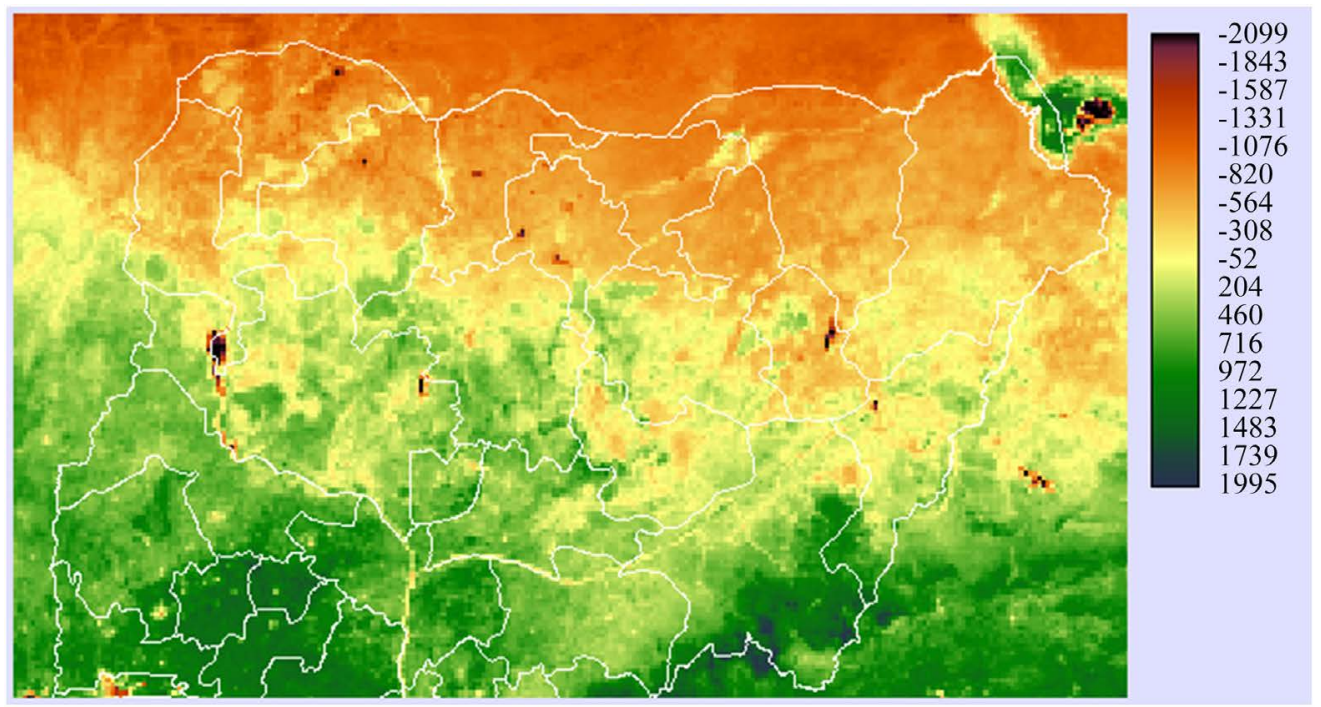

(b)

Figure 2. Component 1 Image and its corresponding graph of Loadings.

northeast ecological zones generally appearing in brown (when viewed in colour) indicating less vegetation vigour. On the other hand, areas that are highly correlated with the loading scores are located in the southern part of the northern fringes and pockects of reserved areas (located partly in Kwara, Kogi, Benue and Taraba States and partly falling in republic of Cameroon) appearing in green colours indicating more vegetation vigour. The loadings scores on the other hand show positive correlations between the component image and the entire 
NDVI time series dataset. The higher peaks are located in November, 2005, 2006 and 2008 while the lower peaks on the graph are located in August 2005, August 2006 and September, 2007.

\subsection{Component 2 and Loading Scores}

Component 2 image in Figure 3(b) is an illustration of the first change component that differs from Component 1 explaining about $8 \%$ of the total variance of the original time-series dataset used as input in the PCA procedure. Its corresponding loading graph shows a pattern of cyclic trend showing positive scores and peaks mostly in September of each year except in August 2006 while negative scores with lower peaks are mostly in February and March. The positive peaks correspond with the peaks of rainy seasons in most areas across the whole study area centered on Northern Nigeria, while the negative peaks correspond with the dry seasons between January and March of each year. This suggest that reservoirs, irrigation canals, and dams are closely associated with parasitic disease. Road and other constructions that disturb vegetation generally can alter ecological balance and can lead to a shift in vector populations such as snails, mosquitoes, their larvae and their parasites. There are high positive correlations spotted in Bauchi, Yobe and Borno states as well as the border areas between Adamawa state and the neighbouring Cameroon. However, there are also locations of high negative anomaly patterns around Kainji and Lake Chad, along rivers Niger and Benue as well as areas around the forest zones of the southwestern part of the study area. These are likely locations of the vector habitats.

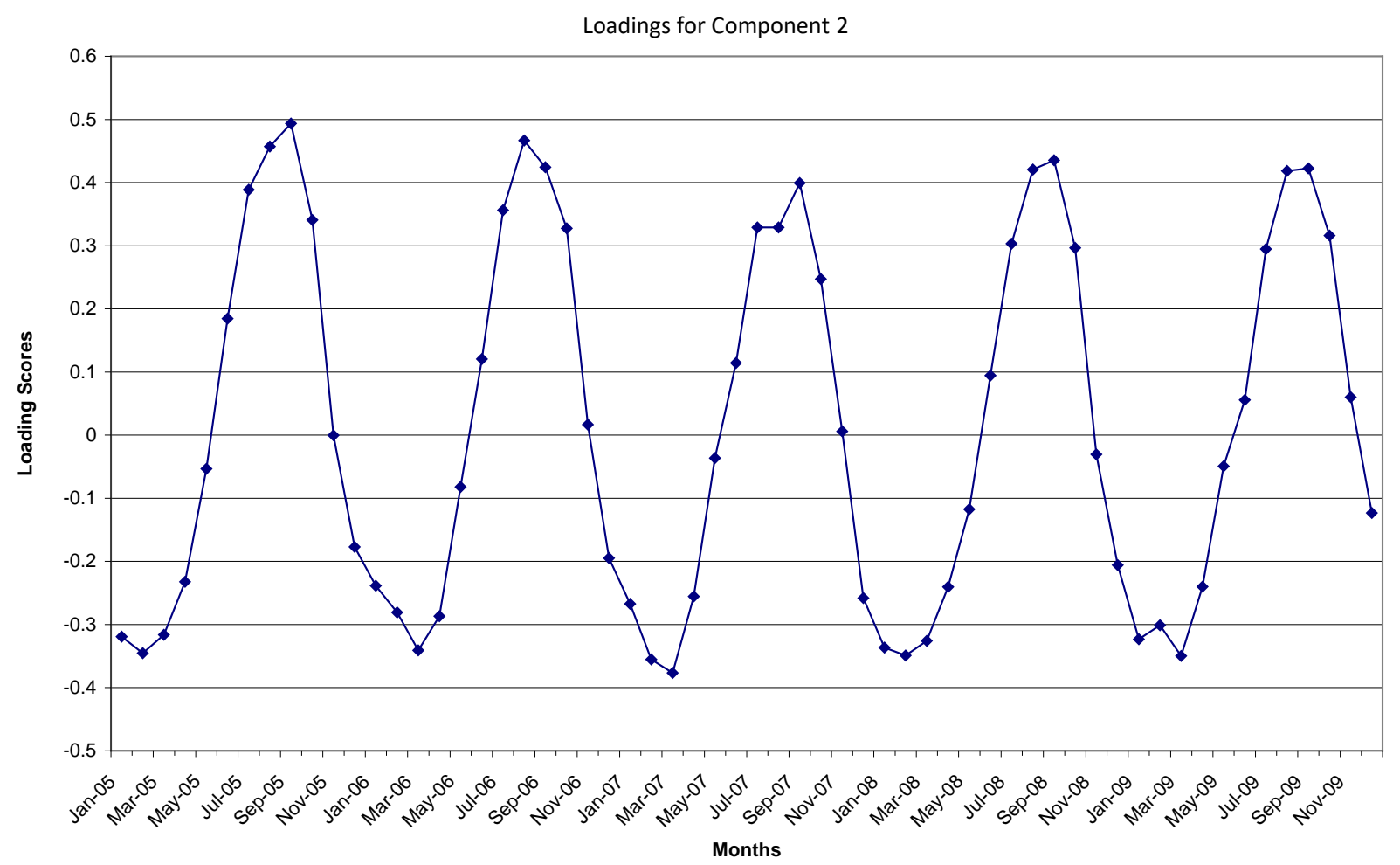

(a) 


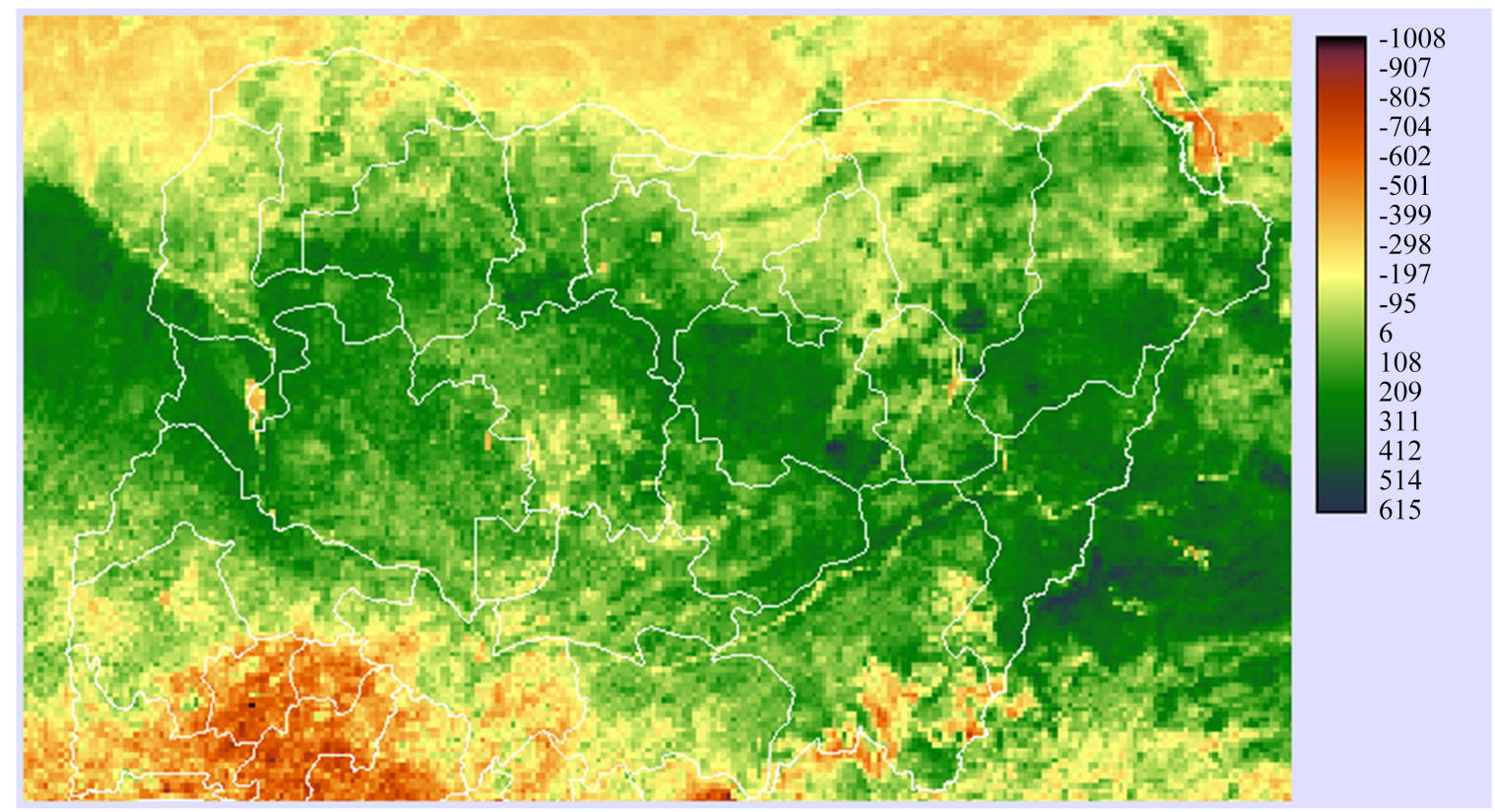

(b)

Figure 3. Component 2 Image and its corresponding graph of Loadings.

\subsection{Component 3 and Loading Scores}

Figure 4(b) shows the second change component image exhibiting about $1.9 \%$ of the variation in the NDVI dataset utilised in the analysis. The corresponding graph of loading scores of this component image, though semi-circular, looks similar to Component 2 in terms of cyclic pattern of vegetation change as shown by the graph of its loading scores. However, the peak of the positive scores on the graph fall in January and September for most years while the negative (low) peaks fall mostly in the month of May. On this component image unlike Component 2 image, most of the positive anomaly patterns are located around forest islands characterized by dry woodland and savanna and along lowland and riverine areas such as the Hadejia-Jama'are and River Rima basins. High negative anomaly patterns however, are located around major dam areas across the northern part of the country. This fluctuated pattern in the profile during this period is indicative of aggregate effect of temperature, precipitation, humidity, solar radiation, and wind which are reflected in the type of vegetation in plant communities that contribute to determining the nature of vector populations and likely habitats of trypanasome vectors.

\subsection{Component 4 and Loading Scores}

This is a change component image showing about $1.2 \%$ of the total variation in the NDVI time-series dataset. The graph of loading for this component image also shows some form of cyclic trend with all positive peak scores on the graph falling in October of all the years. The negative score lower peaks, on the other hand, are mostly in July and August. This component image shows a positive 


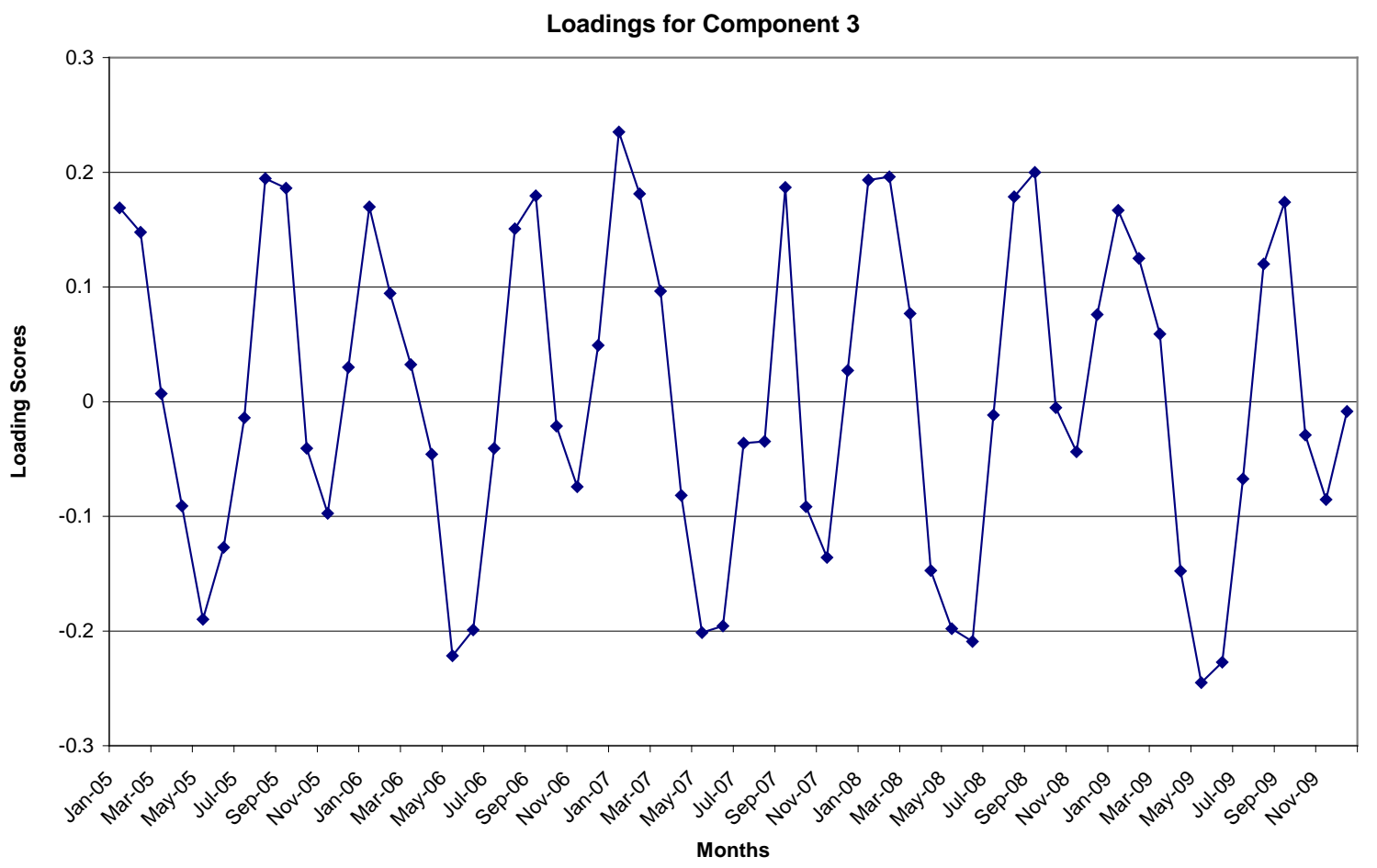

(a)

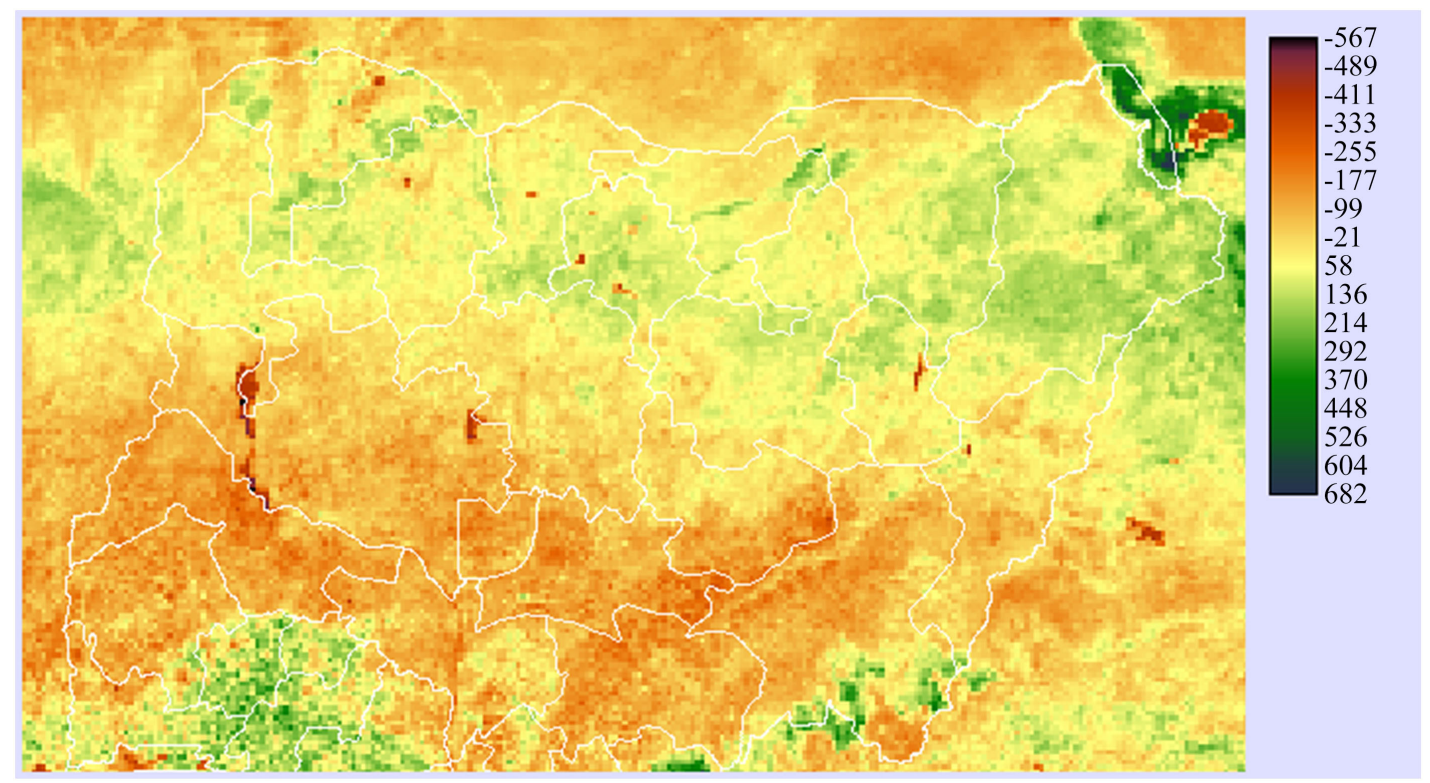

(b)

Figure 4. Component 3 Image and its corresponding graph of Loadings.

anomaly (mostly in green) across the entire northern part of the country with corresponding strong negative anomalies along rivers Niger and Benue and extensively covering parts of Borno and Yobe States (Figure 5(b)). This is unrealistic given the geographical and climatic locations of these different pixels. According to Patz et al. (2000), river blindness is most common along the main river valleys. For example, in Plateau state, the vectors breed during the wet sea- 
son and peak biting density occurs at the height of the rainy season, with more infective parasites at the beginning and end of rains. All these probable vector habitats described were digitized and presented in Figure 6 and location of the areas in states (Table 2).

Loadings for Component 4

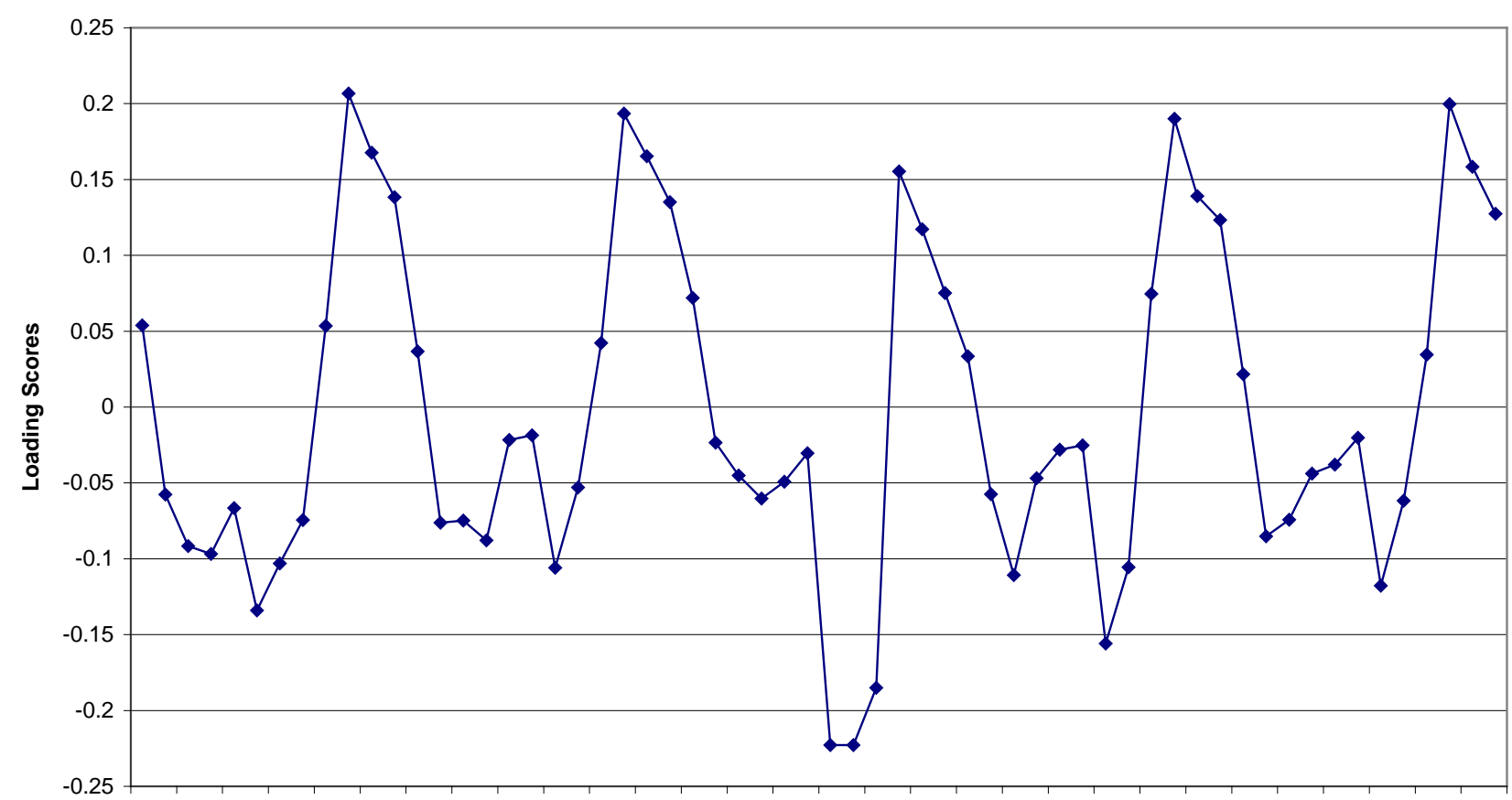

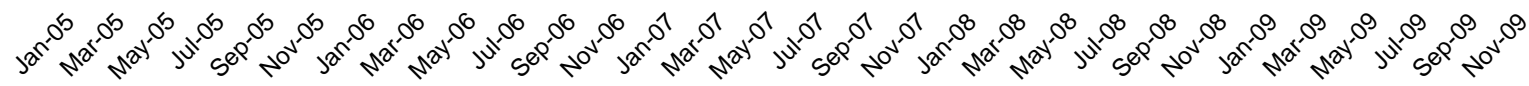
Months

(a)

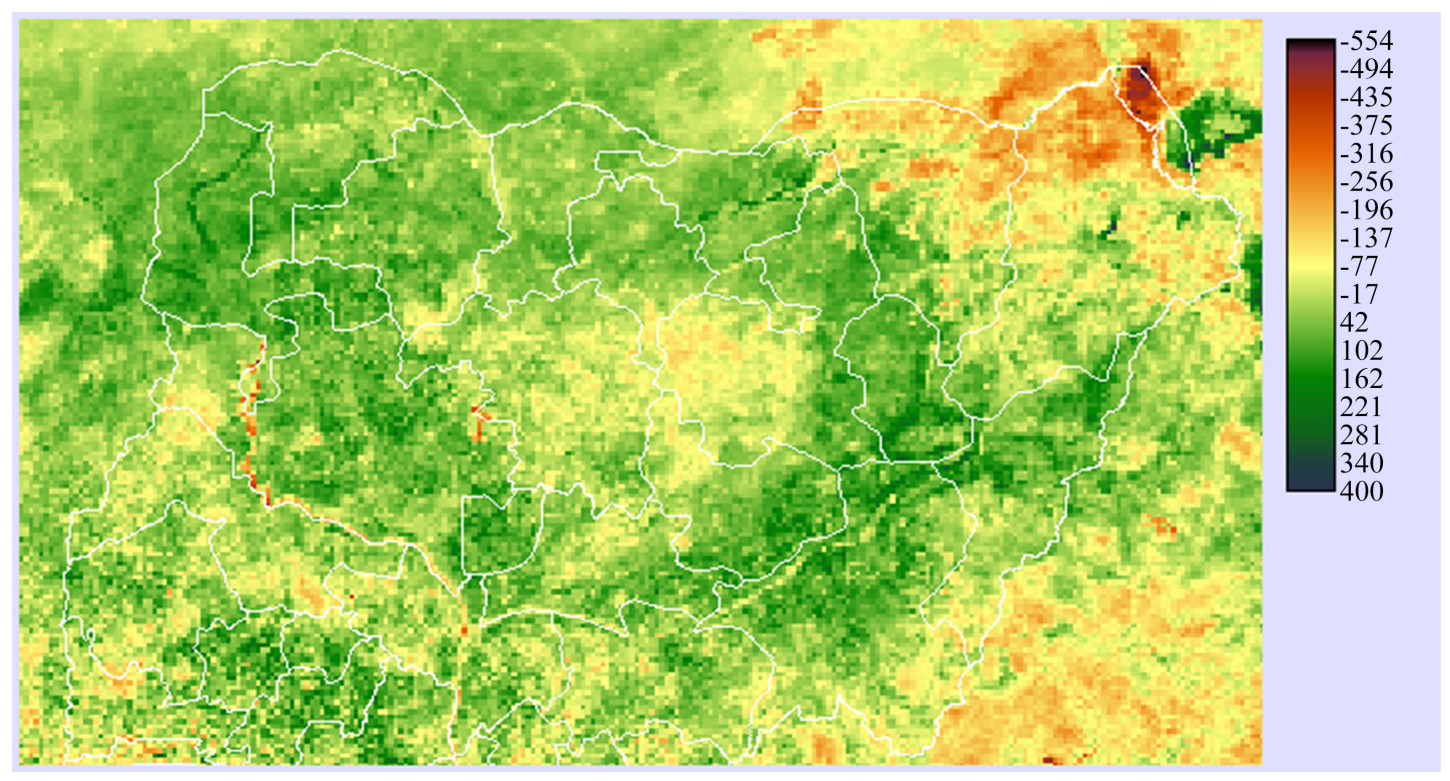

(b)

Figure 5. Component 4 Image and its corresponding graph of Loadings. 


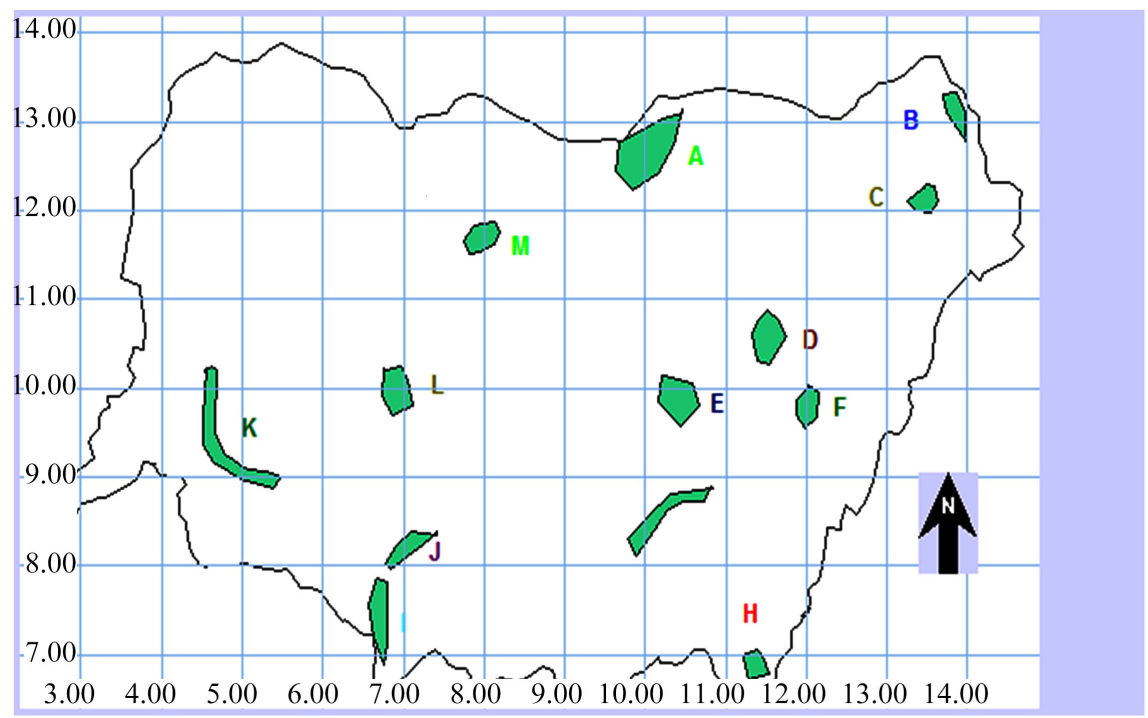

Figure 6. Map of probable habitats of tyrpanasome vectors in northern Nigeria.

\section{Conclusion and Recommendations}

The use of principal component analysis (PCA) as a technique for detecting spatial changes of probable habitat of vectors responsible for trypanosomiasis showed that this cost effective method can be utilised across northern Nigeria in a systematic way. Temporal profiles of anomalous NDVI pixels selected from areas showed that change patterns on component images gave further clues of possible long-term climatic events particularly flooding along river basins which the graph of loading scores highlighted. As it is not economically feasible to raise cattle for example, on large areas of the land due to high prevalence of tsetse flies, cattle breeding/ranching if often confined to dry areas where tsetse flies cannot survive. However, overstocking of these animals is likely to cause land degradation and overgrazing and consequently flooding. Furthermore, where road constructions are extended in the forested and woodland areas particularly in the savanna of northern Nigeria and part of them converted to farmlands by replacing the trees with different crops and tall grasses, it is very likely that such areas will provide comfortable habitats for tsetse colonization. This cost effective approach where remotely sense data analysed within a GIS environment if adopted can assist in highlighting probable habitats of vectors responsible for trypanasomiasis as part of the efforts in eradicating the disease. When the habitats are identified and the areas highlighted their precise locations can be targeted and the vectors eradicated. A higher spatial resolution satellite imageries like Ikonos, Quickbird, GeoEye or Blackbridge in addition to other environmental information can also be combined to enhance further studies for complete eradication of the disease vectors.

\section{Acknowledgements}

The Researchers are grateful to the National Oceanic Atmospheric Administration (NOAA) for the MODIS-CMD dataset, and the Digital Elevation Model 
(DEM) dataset utilized in this study.

\section{Conflicts of Interest}

The authors declare no conflicts of interest regarding the publication of this paper.

\section{References}

Abdullahi, M., \& Yelwa, S. A. (2020). Application of MODIS-NDVI for Vegetation Change Detection across Nigeria from 2000 to 2019. Kaduna State University Environmental Science Journal, 1, 40-47.

Adamu, I. A. (2007). Biodiversity Assessment in the Kwiambana Game Reserve, Zamfara State, Nigeria. Unpublished Ph.D Thesis, Department of Geography, Usmanu Danfodiyo University.

Allsopp, R. (2001). Options for Vector Control against Trypanosomiasis in Africa. Trends in Parasitology, 17, 15-19. https://doi.org/10.1016/S1471-4922(00)01828-6

Ameh, J. A., Egwu, G. O., \& Tijjani, A. N. (2000). Mortality in Sahelian Goats in Nigeria. Preventive Veterinary Medicine, 44, 107-111. https://doi.org/10.1016/S0167-5877(99)00108-7

Anene, B. M., Chime, A. B., Jibike, G. I., \& Anika, S. M. (1991). Prevalence of Trypanosomiasis in Zebu Cattle at Obudu Cattle Ranch-A Tsetse-Free Zone in Nigeria. Preventive Veterinary Medicine, 10, 257-260. https://doi.org/10.1016/0167-5877(91)90011-P

Anyamba, A., \& Eastman, J. R. (1996). Interannual Variability of NDVI over Africa and Its Relation to El-Nino/Southern Oscillation. International Journal of Remote Sensing, 17, 2533-2548. https://doi.org/10.1080/01431169608949091

Anyamba, A., Linthicum, J., Mahoney, R., Tucker, C. J., \& Kelley, P. W. (2002). Mapping Potential Risk of Rift Valley Fever Outbreaks in African Savanna Using Vegetation Index Time Series Data. Photogrammetric Engineering and Remote Sensing, 68, 137-145.

Anyamba, A., Tucker, C. J., \& Eastman, J. R. (2001). NDVI Anomaly Patterns over Africa during the 1997/98 ENSO Warm Event. International Journal of Remote Sensing, 22, 1847-1859. https://doi.org/10.1080/01431160010029156

Ari, M. M., Ogah, D. M., \& Luka, E. G. (2016). Livestock Value Chain Development in Nigeria: Institutional Framework and Opportunities for Chain Actors. Journal of Biology, Agriculture and Healthcare, 6, 34-40. https://www.iiste.org/

Bhunia, G. S., \& Shit, P. K. (2013). Identification of Temporal Dynamics of Vegetation Coverage Using Remote Sensing and GIS (A Case Study of Western Part of West Bengal, India). International Journal of Current Research, 5, 652-658.

Bourn, D., Wint, W., Blench, R., \& Wolley, E. (1994). Nigerian Livestock Resources Surveys. World Bank Animal Review, 78, 49-58.

Chen, J. M. (1996). Evaluation of Vegetation Indices and a Modified Simple Ratio for Boreal Applications. Canadian Journal of Remote Sensing, 22, 229-242.

https://doi.org/10.1080/07038992.1996.10855178

Dransfield, R. D., Williams, B. G., \& Brightwell, R. (1991). Control of Tsetse Flies and Trypanosomiasis: Myth of Reality. Parasitology Today, 7, 287-291.

https://doi.org/10.1016/0169-4758(91)90099-A

Drissi, R., Goutouly, J. P., Forget, D., \& Gaudillere, J. P. (2009). Nondestructive Measurement of Grapevine Leaf Area by Ground Normalized Difference Vegetation Index. 
Agronomy Journal, 101, 226-231. https://doi.org/10.2134/agronj2007.0167

Eastman, J. R., \& Fulk, M. (1993). Long Sequence Time Series Evaluation Using Standardised Principal Components. Photogrammetric Engineering and Remote Sensing, 59, 1307-1312.

FAO in Nigeria (2020). Nigeria at a Glance. http://www.fao.org/nigeria/fao-in-nigeria/nigeria-at-a-glance/en/

Franco, J. R., Simarro, P. P., Diarra, A., \& Jannin, J. G. (2014). Epidemiology of Human African Trypanosomiasis. Clinical Epidemiology, 6, 257-275. https://doi.org/10.2147/CLEP.S39728

Hay, S. I., Packer, M. J., \& Rogers, D. J. (1997). The Impact of Remote Sensing on the Study and Control of Invertebrate Intermediate Hosts and Vectors for Disease. International Journal of Remote Sensing, 18, 2899-2930. https://doi.org/10.1080/014311697217125

ILRAD (International Laboratory for Research Animal Diseases) (1993). Estimating the Costs of Animal Trypanosomiasis in Africa. ILRAD Report, 11, 1-4.

Kalu, A. U. (1995). Prevalence of Trypanosomiasis among Trypanotolerant Cattle at the Lower Benue River Area of Nigeria. Preventive Veterinary Medicine, 24, 97-103. https://doi.org/10.1016/0167-5877(95)00463-7

Kalu, A. U. (1996). Current Status of Tsetse Fly and Animal Trypanosomiasis on the Jos Plateau, Nigeria. Preventive Veterinary Medicine, 27, 107-113. https://doi.org/10.1016/0167-5877(96)01014-8

Kogan, F. N., \& Wei, G. (2000). Using AHVRR Data for the Detection of El-Niňo/La Niňa Impacts on Land Ecosystems. Advanced in Space Research, 26, 1165-1168. https://doi.org/10.1016/S0273-1177(99)01141-2

Laird, M. (1977). Tsetse: The Future for Biological Methods in Integrated Control (p. 220). International Development Research Centre.

Lu, D., Mausel, P., Brondízio, E., \& Moran, E. (2004). Change Detection Techniques. International Journal of Remote Sensing, 25, 2365-2407. https://doi.org/10.1080/0143116031000139863

Mas, J. F. (1999). Monitoring Land-Cover Changes: A Comparison of Change Detection Techniques. International Journal of Remote Sensing, 20, 139-152. https://doi.org/10.1080/014311699213659

Matzke, G. (1983). A Reassessment of the Expected Development Consequences of Tsetse Control Efforts in Africa. Social Science and Medicine, 17, 531-537. https://doi.org/10.1016/0277-9536(83)90295-2

Meyer, A., Holt, H.R., Selby, R., \& Guitian, J. (2016). Past and Ongoing Tsetse and Animal Trypanosomiasis Control Operations in Five African Countries: A Systematic Review. PLoS Neglected Tropical Diseases, 10, e0005247. https://doi.org/10.1371/journal.pntd.0005247

Millington, A. C., Wellens, J., Settle, J. J., \& Saull, R. J. (1994). Explaining and Monitoring Land cover Dynamic in Drylands Using Multi-Temporal Analysis of NOAA AVHRR Imagery. In G. Foody, \& P. Curran (Eds.), Environmental Remote Sensing from Regional to Global Scales (pp. 16-43). John Wiley and Sons Ltd.

Oguntoyinbo, J. S. (1982). Climate 2: Precipitation (1). In K. M. Barbour, J. S. Oguntoyinbo, J. O. C. Onyemelukwe, \& J. C. Nwafor (Eds.), Nigeria in Maps (pp. 16-17). Hodder and Stoughton Ltd.

Olagunju, T. E. (2015). Draought, Desertification and the Nigerian Environment: A Review. Journal of Ecology and Natural Environment, 7, 196-209. 
https://doi.org/10.5897/JENE2015.\%200523

http://www.academicjournals.org/JENE

Patz, J. A., Graczyk, T. K., Geller, N., \& Vittor, A. Y. (2000). Effects of Environmental Change on Emerging Parasitic Diseases. International Journal for Parasitology, 30, 1395-1405. https://doi.org/10.1016/S0020-7519(00)00141-7

Richards, J. A. (1984). Thematic Mapping from Multitemporal Images Data Using Principal Component Transformation. Remote Sensing of Environment, 16, 35-46. https://doi.org/10.1016/0034-4257(84)90025-7

Rogers, D. J., Hay, S. I., \& Packer, M. J. (1996). Predicting the Distribution of Tsetse-Flies in West Africa Using Temporal Fourier Processed Meteorological Satellite Data. Annals of Tropical Medicine and Parasitology, 90, 225-241.

https://doi.org/10.1080/00034983.1996.11813049

Rogers, D. J., Hay, S. I., Packer, M. J., \& Wint, G. R. W. (1997). Mapping Land Cover over Large Areas Using Multispectral Data Derived from the NOAA-AVHRR: A Case Study of Nigeria. International Journal of Remote Sensing, 18, 3297-3303. https://doi.org/10.1080/014311697217107

Samdi, S. M., Abenga, J. N., Attahir, A., Haruna, M. K., Wayo, B. M., Fajinmi, A. O., Sumayin, H. M., Usman, A. O., Hussaina, J. Z., Muhammad, H., Yarnap, J. E., Ovbagbedia, R. P., \& Abdullahi, R. A. (2010). Impact of Trypanosomosis on Food Security in Nigeria: A Review. International Journal of Animal and Veterinary Advances, 2, 47-50.

Simarro, P. P., Cecchi, G., Franco, J. R., Paone, M., Diarra, A., Ruiz-Postigo, J. A., Fèvre, E. M., Mattioli, R. C., \& Jannin, J. G. (2012). Estimating and Mapping the Population at Risk of Sleeping Sickness. PLoS Neglected Tropical Diseases, 6, e1859. https://doi.org/10.1371/journal.pntd.0001859

Singh, A., \& Harrison, A. (1985). Standardized Principal Components. International Journal of Remote Sensing, 6, 883-896. https://doi.org/10.1080/01431168508948511

Sutherst, R. W. (1998). Implications of Global Change and Climatic Variability for Vector-Borne Diseases: Generic Approaches to Impact Assessments. International Journal for Parasitology, 28, 935-945. https://doi.org/10.1016/S0020-7519(98)00056-3

White, F. (1983). The Vegetation of Africa. Natural Resources Research Series No. 20, United Nations Educational, Scientific and Cultural Organisation.

Wilson, A. L., Courtenay, O., Kelly-Hope, L. A., Scott, T. W., Takken, W., \& Torr, S. J. (2020). The Importance of Vector Control for the Control and Elimination of Vector-Borne Diseases. PLoS Neglected Tropical Diseases, 14, e0007831. https://doi.org/10.1371/journal.pntd.0007831

World Health Organization (WHO) (2017). Global Vector Control Response (GVCR) 2017-2030. https://www.who.int/publications/i/item/9789241512978

World Health Organization (WHO) (2020). Trypanosomiasis, African: Factsheet. https://www.afro.who.int/health-topics/trypanosomiasis-african

Xue, J. R., \& Su, B. F. (2017). Significant Remote Sensing Vegetation Indices: A Review of Developments and Applications. Journal of Sensors, 2017, Article ID: 1353691. https://doi.org/10.1155/2017/1353691

Yelwa, S. A., \& Eniolorunda, N. B. (2012). Simulating the Movement of Desertification in Sokoto and Its Environs, Nigeria Using $1 \mathrm{~km}$ Spot-NDVI Data. Environmental Resources Journal, 6, 175-181. https://doi.org/10.3923/erj.2012.175.181

Yelwa, S. A., \& Usman, U. (2017). Integration of Spatial Prediction in the Assessment of Vegetation Productivity in the Northern Part of Nigeria. The American Journal of Climate Change, 6, 360-373. https://doi.org/10.4236/ajcc.2017.62018 
Yelwa, S. A., Sanda, A. B., \& Usman, U. (2019). Spatio-Temporal Assessment of Vegetation Resource Dynamics in Nigeria from SPOT Satellite Imageries. American Journal of Climate Change, 8, 502-519. https://doi.org/10.4236/ajcc.2019.84027

Yu, P., Habtemariam, T., Oryang, D., Obasa., M., Nganwa, D., \& Robnett, V. (1995). Integration of Temporal and Spatial Models for Examining the Epidemiology of African Trypansomiasis. Preventive Veterinary Medicine, 24, 83-95.

https://doi.org/10.1016/0167-5877(95)00465-9 